\title{
Pseudo-3D seismic imaging of Geolin Mounds hydrothermal field in the Southern Okinawa Trough offshore NE Taiwan
}

\author{
Ho-Han Hsu ${ }^{1,2}$, Liang-Fu Lin ${ }^{1}$, Char-Shine Liu ${ }^{2}$, Jih-Hsin Chang ${ }^{3, *}$, Wei-Zhi Liao ${ }^{2}$, Tzu-Ting Chen ${ }^{1}$, \\ Kuo-Han Chao ${ }^{2}$, Sheng-Lung Lin ${ }^{1}$, Hsin-Sung Hsieh ${ }^{4}$, and Song-Chuen Chen ${ }^{5}$ \\ ${ }^{1}$ Institute of Oceanography, National Taiwan University, Taipei City, Taiwan \\ ${ }^{2}$ Ocean Center, National Taiwan University, Taipei City, Taiwan \\ ${ }^{3}$ Geological Survey of Japan, National Institute of Advanced Industrial Science and Technology, Tsukuba, Japan \\ ${ }^{4}$ Marine Instrument Center, National Taiwan University, Taipei City, Taiwan \\ ${ }^{5}$ Central Geological Survey, Ministry of Economic Affair, Taipei City, Taiwan
}

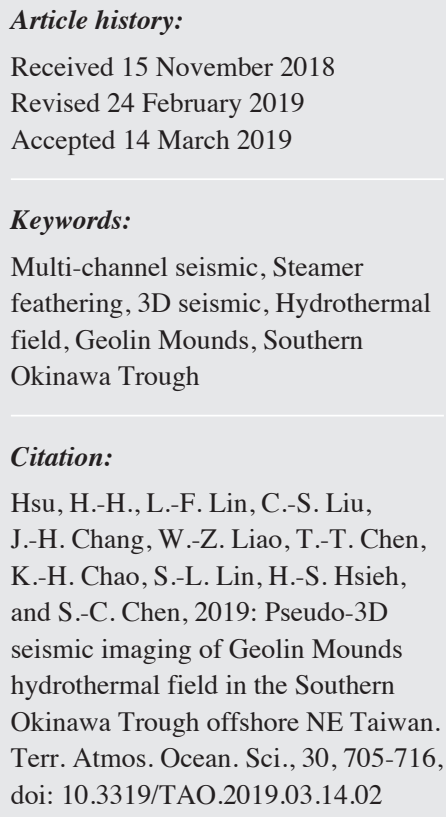

\section{Citation:}

Hsu, H.-H., L.-F. Lin, C.-S. Liu, J.-H. Chang, W.-Z. Liao, T.-T. Chen, K.-H. Chao, S.-L. Lin, H.-S. Hsieh, and S.-C. Chen, 2019: Pseudo-3D seismic imaging of Geolin Mounds hydrothermal field in the Southern Okinawa Trough offshore NE Taiwan. Terr. Atmos. Ocean. Sci., 30, 705-716, doi: 10.3319/TAO.2019.03.14.02

\begin{abstract}
To explore a new discovering hydrothermal field Geolin Mounds in the Southern Okinawa Trough (SOT), a multi-scale geophysical investigation cruise including single-beam echo sounder, sub-bottom profiler (SBP) and multi-channel seismic (MCS) surveys were conducted in 2018 in a new discovering hydrothermal field we named Geolin Mounds. Taking advantage of streamer feathering caused by strong Kuroshio Current during MCS data acquisition, we performed a pseudo-3D processing and produced a pseudo-3D seismic cube. In addition to flare features in water column, "rock grove" like morphological feature above seafloor, widely-distributed amplitude anomalies including blanking zone and high-amplitude reflectors are observed around the Geolin Mounds hydrothermal field in our 2D MCS data. Pseudo3D seismic cube, on the other hand, provide estimation of the areas of blanking zone on selected time slice; furthermore, better characterize the fault structures in the hydrothermal field. The Geolin Mounds is the first disclosed site in the SOT where a hydrothermal field is without underlying submarine volcanos. We thus suggest that the Geolin Mounds hydrothermal field is in its embryo stage of evolution and is constantly supported by vigorous subsurface hydrothermal circulation. Consequently, the Geolin Mounds hydrothermal field may grow sustainably and serves as a good observatory for development of the seafloor edifice and ore mineralization associated with hydrothermal circulation activities.
\end{abstract}

\section{INTRODUCTION}

Hydrothermal activities usually occur along with submarine edifices (e.g., volcanos, mounds and chimneys) and are rich in mineral deposits, reflecting subsurface and active hydrothermal circulation. The formation and evolution of hydrothermal fields are regionally controlled by tectonics such as plate subduction and associated rifting, and are locally controlled by magma activities, host rocks composition, segregation process as well as fluid migration (Von Damm 1990; Charlou et al. 1996; Tivey 2007; Kelley et al. 2012; Minami and Ohara 2017). For last decade, the potential of marine mineral resources in hydrothermal fields enriched by

\footnotetext{
* Corresponding author

E-mail: jihhsin.chan@aist.go.jp
}

hydrothermal circulation that expedite chemical exchanges between hydrothermal fluid and its surrounding crust is receiving increasing attention, especially in the Okinawa Trough (e.g., Inagaki et al. 2006; Ishibashi et al. 2015; Nozaki et al. 2016; Toki et al. 2016; Minami and Ohara 2017), which is a back-arc basin at rear side of the Ryukyu arctrench system along the tectonic boundary between the Eurasian Plate and subducting Philippine Sea Plate (Lee et al. 1980; Letouzey and Kimura 1986; Sibuet et al. 1987, 1998).

Seafloor hydrothermal activities in the Okinawa Trough have been found since late 1970s (Herman et al. 1979; Uyeda 1987), and then their related hydrothermalism have been also introduced (e.g., Kimura et al. 1988; Halbach et al. 1989; Sakai et al. 1990; Glasby and Notsu 2003). 
Active venting hydrothermal chimneys and mounds in hydrothermal fields have been reported by their morphological features, heat flow anomalies and specifically geochemical features in the Okinawa Trough such as Jade Hydrothermal Field (Halbach et al. 1989; Sakai et al. 1990; Luders and Niedermann 2010), Yonaguni Knoll IV (Inagaki et al. 2006; Nunoura et al. 2010; Ishibashi et al. 2015), Hatoma Knoll (Toki et al. 2016), Hakurei Hydrothermal Field (Ishibashi et al. 2014, 2015), and Gondou hydrothermal field (Minami and Ohara 2017). These submarine volcanic activities and active hydrothermal vents sites are characteriszd by hydrothermal circulation with high temperature anomalies (Herman et al. 1979; Yamano et al. 1989; Sakai et al. 1990; Kinoshita and Yamano 1997; Shyu and Liu 2001; Glasby and Notsu 2003; Inagaki et al. 2006; Ishibashi et al. 2015). Except Yonaguni Knoll IV, most of the studied hydrothermal field of the Okinawa Trough, however, are found in central part of the Okinawa Trough.

Recently, a new hydrothermal field we named Geolin (rock grove in Taiwanese) Mounds was found by after deeptowed side-scan (Hsu 2017; Tsai et al. 2019), deep-towed camera (Wang 2016; Chou et al. 2019), in the Southern Okinawa Trough (SOT; Fig. 1) and was characterized by positive temperature anomalies as those fields in central part of the Okinawa Trough (Glasby and Notsu 2003; Ishibashi et al. 2015; Chiao 2017; Liu 2017). While the natures of the Geolin Mounds is not fully understood due to insufficient geophysical surveys and lack of high quality images. To better image
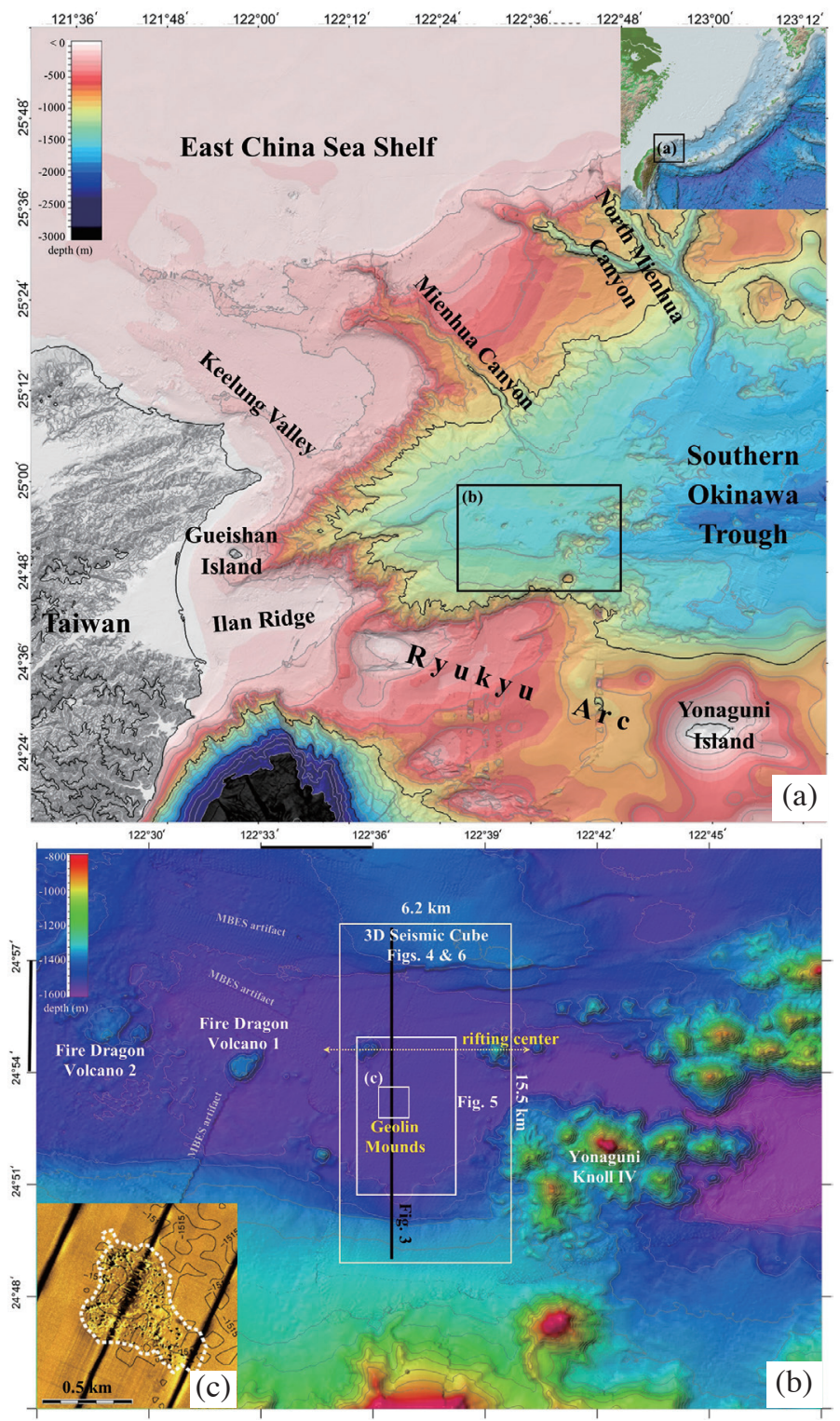

Fig. 1. (a) Regional bathymetry and (b) bathymetry chart with presented data in the study area. The Geolin Mounds hydrothermal field is indicated by (c) deep-towed side-scan image (modified from Hsu 2017). 
the Geolin Mound, a multi-scale geophysical survey including multi-channel seismic data (MCS), sub-bottom profiles (SBP) and echo sounder was carried out in 2018. In addition to conventional MCS data acquisition, we in particularly performed a pseudo-3D processing by taking advantage of streamer feathering owing to strong seasonal current Kuroshio. Combined 2D MCS profiles and a pseudo-3D MCS cube data demonstrates subsurface structural features in great detail. The Geolin Mounds is considered in its embryo stage of evolution and is the first site in the SOT where a hydrothermal field is without underlying submarine volcanos. Our comprehensive seismic 2D/3D imaging results can provide essential information about this newly discovered hydrothermal field and give a first geophysical insights into this hydrothermal site within a back-arc extension system.

\section{GEOLOGICAL BACKGROUND}

The Okinawa Trough is an incipient and intracontinental back-arc basin that has formed at the rear side of the Ryukyu arc-trench system since Late Miocene (Hirata et al. 1991; Miki 1995; Shinjo et al. 1999; Shinjo and Kato 2000; Chung et al. 2000). It extends from the southwest Kyushu Island, Japan to the offshore of northeast Lanyang Plain, Taiwan. The width of the Okinawa Trough varies from about $230 \mathrm{~km}$ with about $200 \mathrm{~m}$ water depth in its north to $60-100 \mathrm{~km}$ with the maximum water depth $\sim 2300 \mathrm{~m}$ in its south (Sibuet et al. 1998). The earliest opening of the Okinawa Trough may begin near middle part of the Okinawa Trough at 10 - $6 \mathrm{Ma}$ (Shinjo et al. 1999). Following the south-westward encroachment of the Ryukyu arc-trench system, the SOT began to occur at $\sim 2 \mathrm{Ma}$.

As the latest part of the Okinawa Trough opening, the SOT has experienced multiple extension periods during the evolution of the trough due to crustal thinning (Park et al. 1998; Sibuet et al. 1998). The crustal thinning of the SOT area features in successive extensional phases of different orientations and local magmatism (> 70 active submarine volcanos; Sibuet et al. 1998; Chung et al. 2000). The excessive magmatism may thus pass through shallow strata and eventually reach the seafloor with the extensional normal faults as conduits (Sibuet et al. 1998). This structural framework and vigorous volcanic activities similarly provide the conduits for hydrothermal fluid as well as necessary heat source in a hydrothermal field (Inagaki et al. 2006; Ishibashi et al. 2015; Minami and Ohara 2017).

\section{METHODOLOGY}

\subsection{Data Acquisition}

The MCS data used in this study were collected on R/V Ocean Researcher I (ORI) in 2017 by Institute of Oceanography, National Taiwan University (Figs. $1 b$ and 2a). The source of MCS system is an airgun array within 415 cubic inch total volume with $\sim 25 \mathrm{~m}$ shot spacing (4.86 knots ship speed with $10 \mathrm{~s}$ shot interval). The MCS data were received via a streamer of $1.5 \mathrm{~km}$ long and 120 channels. The channels interval is $12.5 \mathrm{~m}$ with 1 -ms sampling rate. Two GPS systems installed both in the source side and tail buoy after the streamer together with 6 gyro compasses in different sections of streamer are used to locate our equipment and to build geometries of our seismic data. To the MCS data, the shipboard EA60 single-beam echo sounder, ADCP (acoustic Doppler current profiler) and Bathy-2010p chirp sonar data were acquired underway.

During the cruises, the survey systems, i.e., MCS were unexpectedly and critically affected by the Kuroshio Current, the western boundary current of the Pacific flowing northward (Yang et al. 1999; Jian et al. 2000; Tang et al. 2000; Liang et al. 2003; Hsin et al. 2008) at a speed ranged from 1.5 to 3 knots. The streamer could even feather at angles more than 40 degrees (Fig. 2), depending on the ship courses and the current speeds. When the Kuroshio Current came at right angle to survey courses, the far end of the streamer (1500 km long with $145 \mathrm{~m}$ tow-leader) could deviate more than $1060 \mathrm{~m}$ away from the rear of research vessel, resulting in common depth points (CDPs) lying in a planar swath within more than $530 \mathrm{~m}$ width instead of being in a linear distribution along the ship track.

When strong streamer feathering occurs, the quality of 2D seismic dataset may be reduced in conventional seismic data processing flow. Apparently, if CDPs are distributed in a swath, the 2D binning and stack will combine lateral signals, and then the dataset cannot well present structures under seafloor (Yilmaz 2001; Nedimović et al. 2003). Nevertheless, this drawback to 2D seismic line caused by strong streamer feathering could create an opportunity for 3D seismic cube building. Therefore, we thus took advantage of the feathered and densely-distributed (370 m; 0.2 arc minute) spacing 2D seismic lines and the swath-distributed CDPs and produced a pseudo-3D seismic dataset. A total number of $19 \mathrm{~N}-\mathrm{S}$ trend seismic surveying lines were designed and acquired in the Geolin Mounds hydrothermal site.

\subsection{Data Processing}

The MCS data were processed by using the ProMAX seismic data processing software. For the 2D seismic data, we applied trace editing, geometry building, bandpass filtering, amplitude compensation, predictive deconvolution, spiking noise removal, velocity analysis, normal move-out correction, trace balance, stacking, water velocity F-K time migration, and water column mute tools. Moreover, when strong streamer feathering effect occurred, exterminating of far offset signals is a trade-off processing to increase 2D seismic imaging qualities

Instead of 2D geometry, stack and water velocity migration, 3D binning for geometry building, stacking and 3D 

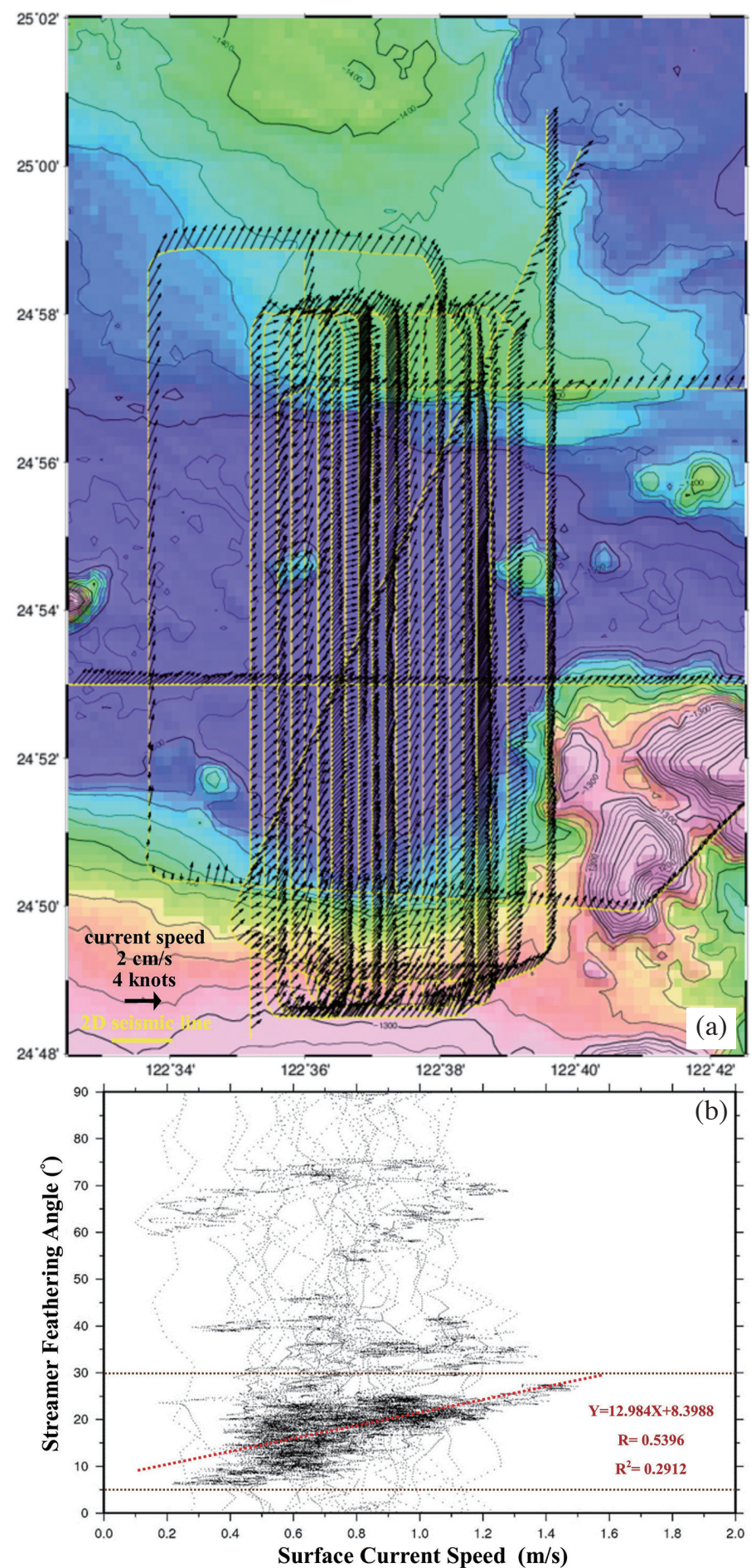

Fig. 2. (a) Surface current speeds of the Kuroshio measured by the R/V ORI ADCP system along seismic survey lines. (b) Relation of current speeds and streamer feathering angles. Most of feathering angles which are larger than $40^{\circ}$ happened when the R/V ORI was turning. 
phase-shift migration based on pseudo-3D velocity volume extracted from 2D velocity analysis results were employed. Because a consistent current condition without any velocity and direction changes in 3-day field work is not realistic, the streamer feathering level also changed. As a result, the swath of CDPs distribution also varied and it made unregularly sampling in each 3D cell, and moreover caused few "no trace" zone between in two in-lines, especially when the Kuroshio Current turned into relatively weak. To deal with this issue, we tried to set different 3D cell sizes to make balance between the data resolution and the numbers of no data cell. Considering an ideal CDP interval $(6.25 \mathrm{~m})$ is a half of channel interval $(12.5 \mathrm{~m})$, a $50 \mathrm{~m} \times 12.5 \mathrm{~m}$ cell size has been decided after several trials with different cell sizes and then we built the first 3D seismic cube combing with 124 in-lines and 1240 crosslines. After 3D stack, we applied trace filtering, equalizing, regularizing, and interpolating on the post-stack traces in crossline direction before 3D migration. The purpose of above processes is to balance signals recorded by different channels from near to far offsets, infilled gap areas and get a better imaging result in the seismic cube (Biondi 2006). Based on the pseudo-3D velocity volume information, time-depth conversion processing was applied as the final step. The final 3D seismic cube which covers $15.5 \mathrm{~km} \times 6.2 \mathrm{~km}$ area within $25 \mathrm{~m} \times 12.5 \mathrm{~m}$ cell size is for further interpretation works. Then, all 2D seismic profiles and 3D seismic cube were analyzed and interpreted through the IHS Kingdom software. We also applied different post-stack seismic attribute analyses into the final 3D seismic cube to emphasize sedimentary and structural features in the seismic dataset. A $96.1 \mathrm{~km}^{2}$ area 3D seismic cube was built and covered the Geolin Mounds hydrothermal site, two submarine volcanos along the rifting center of SOT and series of normal faults related to back-arc extensions (Figs. $1 \mathrm{~b}$ and 3 ).

\section{RESULTS}

\subsection{Streamer Feathering Analysis}

A total number of 22077 shots of seismic data were collect in 3D cube area (Table 1). We compared the relationship between surface current speeds and streamer feathering angles of streamer within all shots. A SW-NE direction of current with $0.1-1.5 \mathrm{~m} \mathrm{~s}^{-1}(0.2-3 \mathrm{knots})$ of speed cause the feathering angles ranging mainly from $5-40^{\circ}$ (Fig. 2). Few of feathering angles which are larger than $40^{\circ}$ occurred due to the turning of ship. About $40 \%$ shots have streamer feathering angles $10-20^{\circ}$ and $20-30^{\circ}$, respectively (Table 1 ).

In the range of $5-30^{\circ}$, a roughly linear correlation between surface current speeds and streamer feathering angles, and the correlation coefficient $\mathrm{R}$ is 0.54 . However, when the surface current strengthened to more $1.4 \mathrm{~cm} \mathrm{~s}^{-1}$, the streamer feathering angle changes were not reflected to surface current speed. In the case we met in 2017, we tried to use $370 \mathrm{~m}$ line spacing to build a pseudo-3D cube in the Geolin Mounds hydrothermal site. However, considering our streamer feathering analysis result, a narrower line spacing is better. It means our 3D seismic dataset quality can be improved if less than $200 \mathrm{~m}$ (about 0.1 arc minute) line spacing could be designed during data acquisition in this study.

\subsection{Two-Dimensional Dataset}

Several geophysical features are present in our 2D seismic dataset. A $\sim 500 \mathrm{~m}$ wide and $\sim 900 \mathrm{~m}$ high flare feature is observed in our echo sounder and MCS seismic data (Figs. 4a and c). In addition, the shipboard SBP data show a $\sim 3$ m relief $(\sim 4$ ms two-way-travel time, TWTT) in the Geolin Mounds area (Fig. 4b). These observations seem to support an active seafloor feature, and are consistent to results from previous deep-tow side-scan sonar survey (Fig. 1, Hsu 2017). Besides, a widely-distributed blanking zone below the Geolin Mounds is also observed by our multiple geophysical tools. The SBP observation shows that the area of the blanking zone is about 3.5-time wider in the deep strata than the area of its bathymetric expression on the seafloor (Fig. 4b). In 2D MCS profiles, the blanking zone occur at least $0.4 \mathrm{~s}$ TWTT beneath seafloor, showing a widely-distributed amplitude anomalies (Fig. 4a). In the blanking zone, some reflectors still can be traced to adjacent sedimentary layers. We ascribe this "pinchout" of blanking zone as a result of lateral change of stratigraphic impedances.

Fault structures are extensively identified around the Geolin Mound. Some of the fault structures crop out along the base of the slope; others are buried, covered by latest seafloor sediments. We note that the other fault structures, interestingly, are adjacent to the subsurface blanking zone of the Geolin Mound, as can be seen in Fig. 4a. As a candidate of fluid migration pathways, the identification of fault structures should be significant for hydrothermal fields (e.g., Planke et al. 2005; Hansen and Cartwright 2006; Sun et al. 2014). While it is always limited when we intend to trace the fault structure laterally with 2D seismic dataset. The aid of the 3D MCS data on fault structure identifications become helpful and will be discussed in section 4.3.

\subsection{D Seismic Cube}

3D seismic dataset not only provide better horizontal coverage with the aid of the time slices including both depth slice or geological time slice, but also provides perspective visualization that allow us to identify different targets with greater precision. These advantages help better estimate the distributions of stratigraphic and faults structures. For example, we can see that the blanking zone are surrounded by strong reflectors at all times and that the distribution of the blanking zone is highly variable in our 3D seismic cube (Fig. 5). With the aid of time slices, the area of blanking 


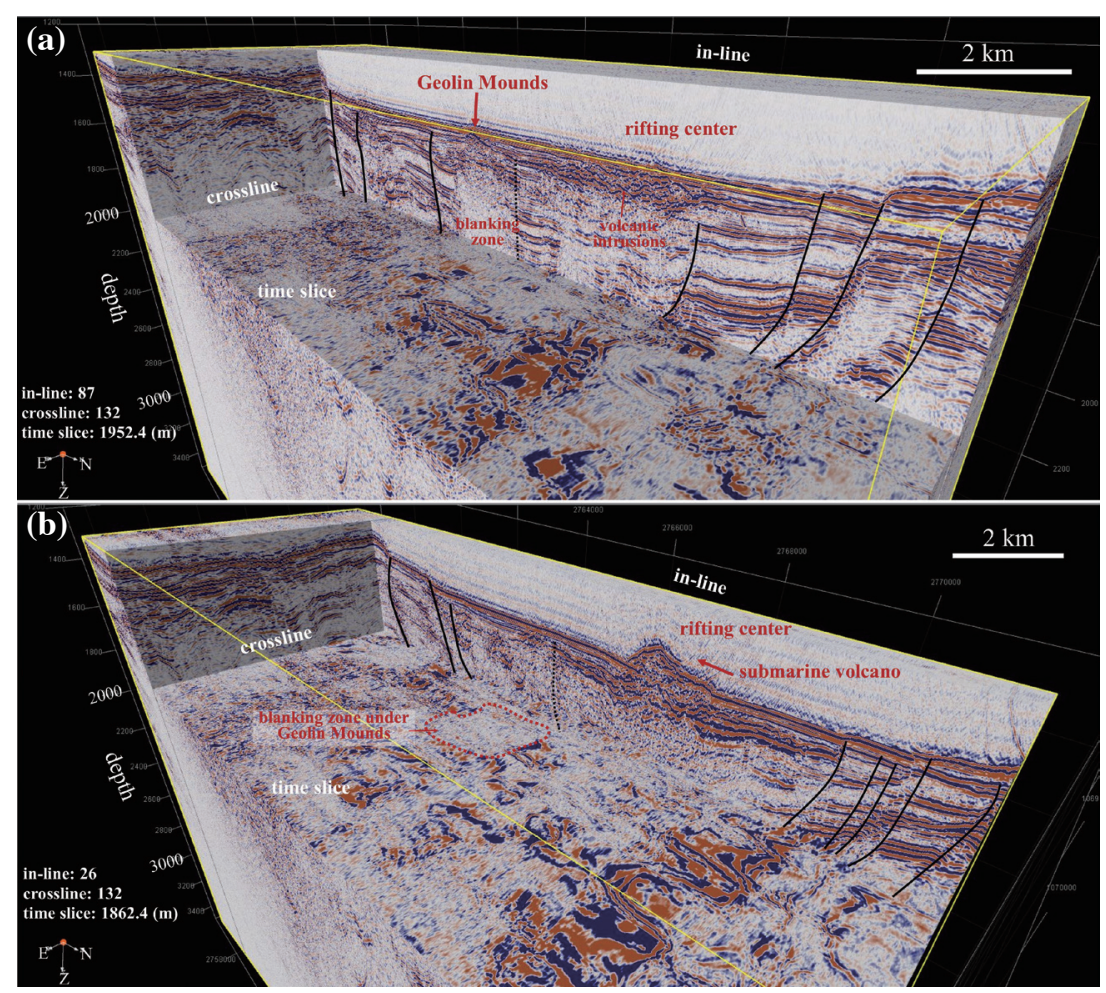

Fig. 3. Depth converted pseudo-3D seismic cube in the study area. The blanking zone could be clearly identified and measured in pseudo-3D seismic cube. The black lines indicate fault structures. A probable fault marked by dash lines in different in-lines can be traced between Geolin Mounds and the rifting center of SOT.

Table 1. Conditions of our seismic data affected by streamer feathering effect during 2017 data acquisition and their related CDPs (common-depth-points) swath width.

\begin{tabular}{c|ccccc}
\hline Streamer Shifting Angle (degree) & $0-10$ & $10-20$ & $20-30$ & $30-40$ & $>40$ \\
Number of Shots in 3D Cube & 1505 & 8595 & 8641 & 2306 & 1030 \\
Percentage (\%) & 6.8 & 38.9 & 39.2 & 10.4 & 4.7 \\
Streamer feathering (m) & $0-143$ & $143-563$ & $563-823$ & $823-1057$ & $>1057$ \\
Width of CDPs Swath (m) & 72 & 282 & 412 & 529 & $>529$ \\
\hline
\end{tabular}

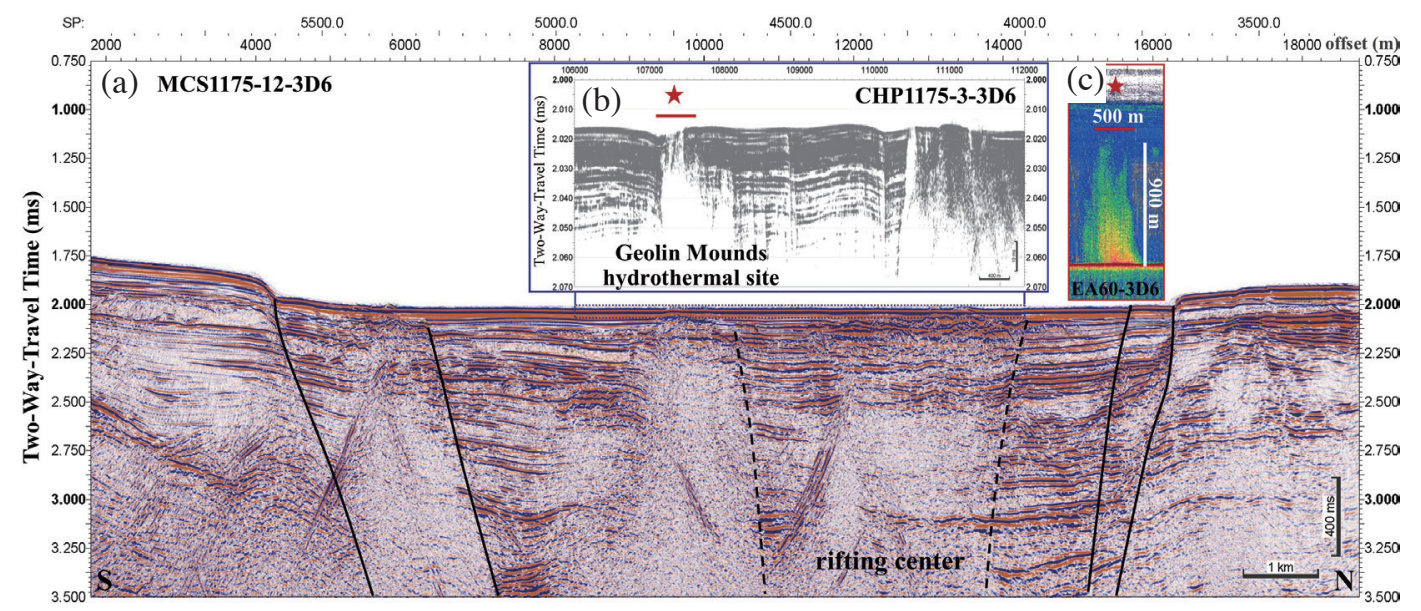

Fig. 4. (a) The 2D MCS profile across the Geolin Mounds hydrothermal site and whole survey area. See the location in Fig. 1. (b) Selected SBP data showing the blanking characteristics at the shallow part of the Geolin Mound. See the blue box and lines in (a) for the location. (c) Selected echo sounder profile showing the flare feature. See the red line in (b) for the location. An active flare can be observed above the site (marked by red star). We note that the Geolin Mounds hydrothermal field is located south of the rifting center of the SOT where several normal faults had developed. 


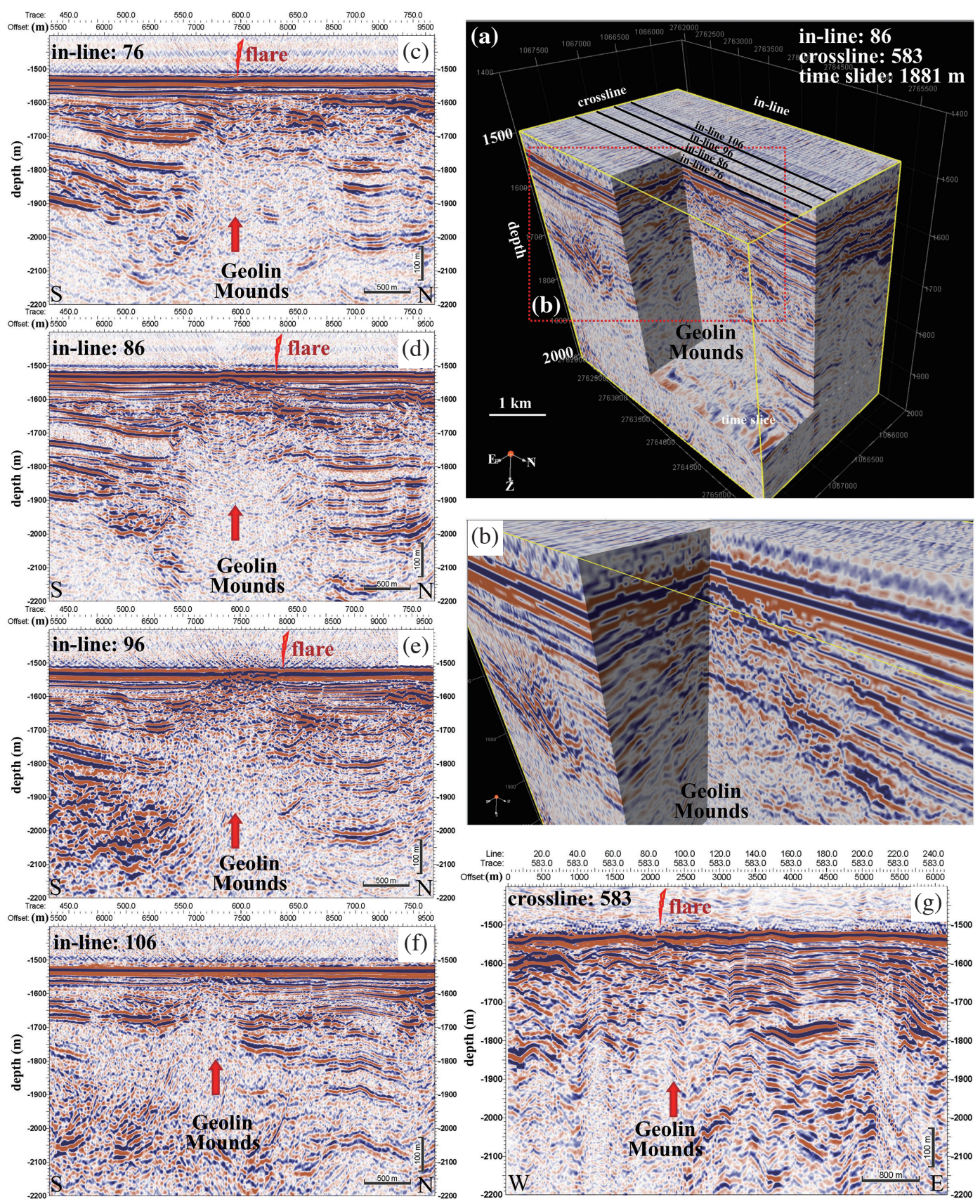

Fig. 5. Close-up views of the Geolin Mounds hydrothermal field in 3D seismic dataset. The geometry of under seafloor structure of Geolin Mounds can be well defined by pseudo-3D seismic cube in (a) and (b). (c) to (f) and (g) are in-lines and a cross-line across the Geolin Mounds, showing the flares above the mounds and the subsurface blanking zone. Red arrows indicate the possible upward migrating hydrothermal fluids.

zone at specific depths could be estimated. For example, the area of blanking zone beneath the Geolin Mounds at the $1881 \mathrm{~m}$ deep is about $1.38 \mathrm{~km}^{2}$ (Figs. 3 and 5). This area is about 4 times greater than expression of the Geolin Mounds on the seafloor $\left(0.34 \mathrm{~km}^{2}\right)$, indicating a larger area affected by subsurface hydrothermal circulation. Our 3D seismic cube also reveals more information about the flare feature observed in echo-sounder and 2D MCS data. It seems that the observed flare features mostly occur along an upward weakening high-amplitude reflectors. This upward weakening amplitude of reflector may indicate hydrothermal fluids migrating from the deep to shallow strata.

The 3D MCS seismic cube also exceptionally presents the extension of the fault structures with the aid of seismic attribute analyses. The fault structure developed between Geolin Mounds and rifting center of SOT are observed in 2D MCS dataset, while the fault offsets seem obscure probably because of the effect of the blanking zone (Fig. 4). Here 
we applied variance seismic attribute analysis, which improves images of fault surfaces on the basis of trace-to-trace variability that produces interpretable lateral changes in acoustic impedance in 3D seismic cube (Aqrawi et al. 2011; Randen et al. 2001). The spatial distribution of the blanking zone and fault structures are thus distinct and the fault surfaces become easier to define. Two linear structures close to the Geolin Mounds hydrothermal site are thus presented (Fig. 6). We interpreted those linear structures could be two faults developed and affect the blanking zone.

\section{DISCUSSION}

\subsection{Streamer Feathering and Pseudo-3D Seismic Cube Building}

For seismic surveys, a steady sea condition without strong current is idea. Unfortunately, streamer feathering is unable to be avoided due to the current effect of the Kuroshio in our case. Especially, when large streamer shifting angle occurred, conventional 2D seismic processing flows inevitably stack widely distributed reflectors into single CDP; therefore the special resolution of seismic data decrease. Then, how to acquire more information from this adversity and create maximum value becomes important. In this study, we employed pseudo-3D seismic data processing. Depending on swath distributed reflections in each shot, a 3D seismic cube is built to study a hydrothermal field. For 2D seismic images, the imaging results got improved (Figs. 4 and 5), and the 3D visualization and seismic attribute analyzing techniques (Fig. 6) can be applied to help data interpretation. However, some drawbacks of this trial should be remarked.

For true 3D seismic data, regularly distributed as well as high and even folds of traces in each 3D binning cell is preferred. Otherwise, the variances of signals between different 3D cells could not only reflect the sedimentary and structural characteristics under seafloor, but also could be caused by inconsistent and inadequate sampling results. Besides, because we relied on streamer feathering to infill data between each 2D seismic survey lines to increase numbers of both in-lines and crosslines, consequentially, signals from near and far offsets cannot stack into one cell. It means different in-lines are mainly composited by signals only from either near offsets or far offset channels, depending on their distances from each real 2D seismic survey line. It means some characteristics variations in 3D dataset such as frequency and vertical imaging result changes might be untrustworthy to reflect real three-dimensional geological changes. Besides, a strong and changing current effect may decrease signal-noise ratios of collected dataset. The increasing noises due to strong streamer feathering influences undoubtedly level down collected data qualities.

\subsection{Nature of the Geolin Mounds Hydrothermal Site}

The Geolin Mounds hydrothermal site is characterized by the presence of active plume in the water column, "rock grove" like morphological feature identified in the deeptowed equipment on the seafloor (Wang 2016; Hsu 2017), positive temperature anomalies (Chiao 2017), and specific seismic characteristics presented in this study. The flare feature above the Geolin Mounds has been observed in more than 10 surveys during 2016 to 2018, suggesting that the Geolin Mounds hydrothermal site is currently active and is continuously supported by subsurface fluid migration. In fact, some of the observed feature are highly similar to

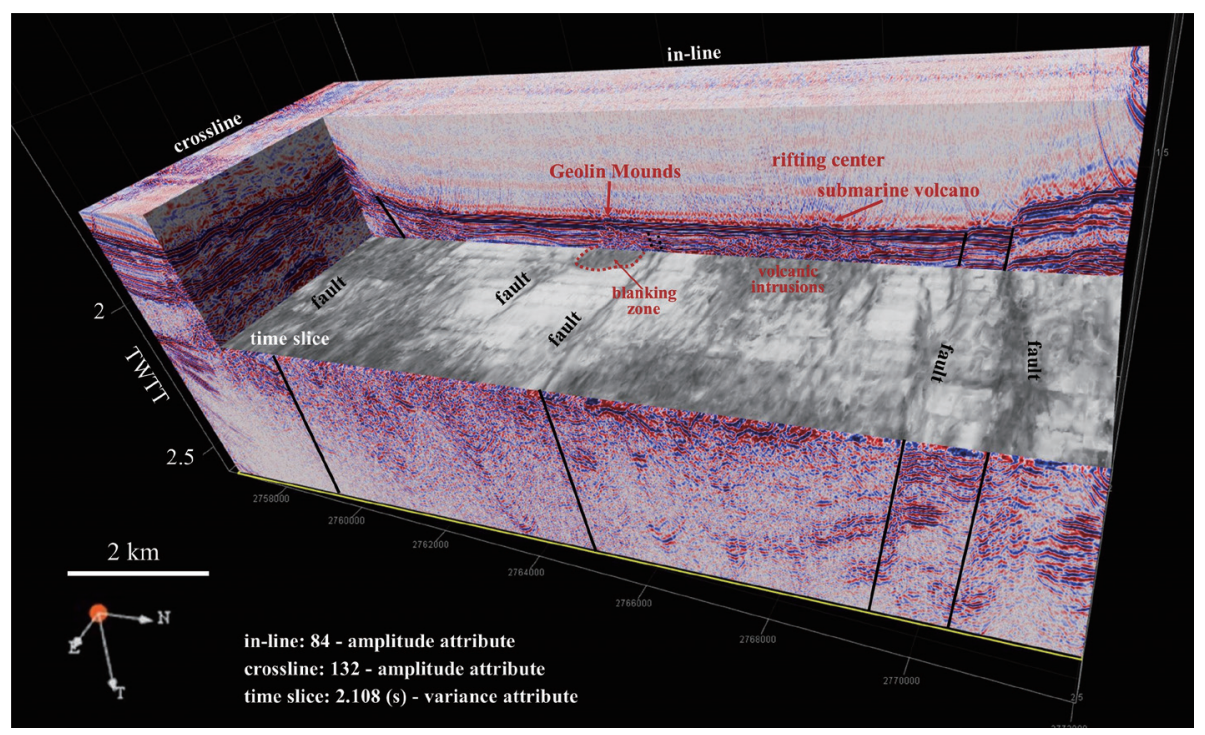

Fig. 6. The result of the variance seismic attribute in a selected time slice (depth slice) of our pseudo-3D seismic cube. The fault structures developed adjacent to the Geolin Mounds could be clearly defined based of this attribute analysis, showing lineations in near W-E direction. 
the Gondou Field in the central part of Okinawa trough and other hydrothermal sites. The Geolin Mounds in the SOT has similar topographic features including spires or small mounds on the seafloor reported in the Gondou Field (Mina$\mathrm{mi}$ and Ohara 2017). Flares existing from the edge of strong reflectors near seafloor and surrounding subsurface blanking zone has been similarly reported like other hydrothermal fields such as Gondou Field and Mothra Hydrothermal Field on Juan de Fuca Ridge (Glickson et al. 2007; Minami and Ohara 2017). Developments of these features may be associated with changes of fluid migration pathways.

A north dipping fault between Geolin Mounds and the rifting center of SOT (Figs. 4 and 6) also features the fluid migration system of the Geolin Mounds site. This hydrothermal circulation and fluid migration system, therefore, are highly likely to be dominated by normal fault structures. In fact, fault structures are common to provide an inherited component for fluid migration (e.g., Planke et al. 2005; Hansen and Cartwright 2006; Sun et al. 2014; Hsu 2017).

We additionally note that the size of the Geolin Mounds is very limited and that there is no large basal mounds or volcanos beneath the Geolin Mounds hydrothermal field. Therefore, we consider that the Geolin Mounds hydrothermal field is plausible in its embryo stage of evolution. The size of the Geolin Mounds will increase progressively to those we can see in the central Okinawa Trough, and become one of great potential submarine observatory for hydrothermal activities once it is sustainably supported by long term upward migrating fluid and hydrothermal circulation. Eventually, vigorous hydrothermal activities can contribute to the formation of large mound structures in the future as long as the hydrothermal fluid source remain supportive. Figuring out structural controls of the Geolin Mounds will improve our understanding of hydrothermal system; furthermore, it will improve the estimation of mineral resource potential in hydrothermal systems.

\section{CONCLUSION}

In this paper, we used different geophysical methods, especially reflection seismic technique to investigate a new discovering hydrothermal field we named Geolin Mounds. Because of the strong Kuroshio Current during seismic data acquisition, serious streamer feathering occurred. We developed the capability to use highly current influenced $2 \mathrm{D}$ seismic data to build the first pseudo-3D seismic cube with a single-streamer seismic acquisition system in the SOT offshore of northeastern Taiwan to study the hydrothermal site. Better imaging results of $2 \mathrm{D}$ seismic profiles and a 3D seismic cube covering $15.5 \mathrm{~km} \times 6.2 \mathrm{~km}$ area with $25 \mathrm{~m} \times$ $12.5 \mathrm{~m}$ special resolution have been successfully produced. Based on 2D and 3D seismic data analysis results, we present the under-seafloor structure of Geolin Mounds hydrothermal field. The area of blanking zone on seismic images which indicates the area influenced by hydrothermal fluid flow under the mounds is at least 4-time larger than the one we observed on the seafloor. It also results in the mounds developing above the seafloor.

Tectonic and structural factors apparently control the formations and evolution of Geolin Mounds hydrothermal field. The volcanic activities and development of faults around the Geolin Mounds due to rifting activity of SOT are suggested to provide heat sources and passing through paths for vents. The faults can serve as robust and long-lived conduits, and the strata nearby the faults could form fractures for hydrothermal flows to the seafloor. These faults can be clearly identified as linear features and be traced in the pseudo-3D seismic attribute dataset. We believe that the Geolin Mounds can continuously build up and be more widely distributed in this geological setting. The investigation of this hydrothermal field can help understanding and evaluating the formation and possible evolutions of metalrich chimneys and mounds which can develop into hydrothermal ore deposits as abundant mineral resources in the hydrothermal system of SOT.

Acknowledgements The authors acknowledge assistance received from members of the Seismic Exploration Laboratory, Institute of Oceanography, Ocean Center, Marine Instrument Center and the crews of the R/V ORI, National Taiwan University (NTU). We thank anonymous reviewers and their comments that greatly help improve this manuscript. This study is supported by the project "Investigation of Mineral Resource Potential in the Offshore Northeastern Taiwan" of Central Geological Survey (CGS), Ministry of Economic Affairs, Taiwan. IHS University Grant program is appreciated for providing the Kingdom software. We thank all the colleagues worked together in this project, especially Mr. Shye-Donq Chiu from NTU as well as Dr. Yun-Shuen Wang and Ms. Yi-Jung Lin from CGS, Taiwan.

\section{REFERENCES}

Aqrawi, A. A., T. H. Boe, and S. Barros, 2011: Detecting salt domes using a dip guided 3D Sobel seismic attribute. SEG Technical Program Expanded Abstracts 2011, Society of Exploration Geophysicists, 10141018, doi: 10.1190/1.3627377. [Link]

Biondi, B. L., 2006: 3D Seismic Imaging, Investigations in Geophysics Series No. 14, Society of Exploration Geophysicists, Tulsa, Oklahoma, U.S.A., 247 pp, doi: 10.1190/1.9781560801689. [Link]

Charlou, J. L., Y. Fouquet, J. P. Donval, J. M. Auzende, P. Jean-Baptiste, M. Stievenard, and S. Michel, 1996: Mineral and gas chemistry of hydrothermal fluids on an ultrafast spreading ridge: East Pacific Rise, $17^{\circ}$ to $19^{\circ} \mathrm{S}$ (Naudur cruise, 1993) phase separation processes controlled by volcanic and tectonic activity. J. Geophys. 
Res., 101, 15899-15919, doi: 10.1029/96JB00880. [Link]

Chiao, L. Y., 2017: Geological Investigation of Mineral Resource Potential in the Offshore Northeastern Taiwan: Heat flow investigation and data analysis (2/4). Report of Central Geological Survey, 106-12-B. (in Chinese with English abstract)

Chou, Y.-C., C.-C. Wang, H.-H. Chen, and Y.-H. Lin, 2019: Seafloor characterization in the southernmost Okinawa Trough from underwater optical imagery. Terr. Atmos. Ocean. Sci., 30, 717-737, doi: 10.3319/ TAO.2019.03.14.01. [Link]

Chung, S. L., S. L. Wang, R. Shinjo, C. S. Lee, and C. H. Chen, 2000: Initiation of arc magmatism in an embryonic continental rifting zone of the southernmost part of Okinawa Trough. Terr. Nova, 12, 225-230, doi: 10.1046/j.1365-3121.2000.00298.x. [Link]

Glasby, G. P. and K. Notsu, 2003: Submarine hydrothermal mineralization in the Okinawa Trough, SW of Japan: An overview. Ore Geol. Rev., 23, 299-339, doi: 10.1016/j.oregeorev.2003.07.001. [Link]

Glickson, D. A., D. S. Kelley, and J. R. Delaney, 2007: Geology and hydrothermal evolution of the Mothra hydrothermal field, Endeavour Segment, Juan de Fuca Ridge. Geochem. Geophys. Geosyst., 8, Q06010, doi: 10.1029/2007gc001588. [Link]

Halbach, P., K. Nakamura, M. Wahsner, J. Lange, H. Sakai, L. Käselitz, R.-D. Hansen, M. Yamano, J. Post, B. Prause, R. Seifert, W. Michaelis, F. Teichmann, M. Kinoshita, A. Märten, J. Ishibashi, S. Czerwinski, and N. Blum, 1989: Probable modern analogue of Kuroko-type massive sulphide deposits in the Okinawa Trough back-arc basin. Nature, 338, 496-499, doi: 10.1038/338496a0. [Link]

Hansen, D. M. and J. Cartwright, 2006: The three-dimensional geometry and growth of forced folds above saucer-shaped igneous sills. J. Struct. Geol., 28, 15201535, doi: 10.1016/j.jsg.2006.04.004. [Link]

Herman, B. M., R. N. Anderson, and M. Truchan, 1979: Extensional tectonics in the Okinawa Trough: Convergent Margins. In: Watkins, J. S., L. Montadert, and P. W. Dickerson (Eds.), Geological and Geophysical Investigations of Continental Margins, American Association of Petroleum Geologists, 199-208, doi: 10.1306/M29405C13. [Link]

Hirata, N., H. Kinoshita, H. Katao, H. Baba, Y. Kaiho, S. Koresawa, Y. Ono, and K. Hayashi, 1991: Report on DELP 1988 cruises in the Okinawa Trough: Part 3. Crustal structure of the southern Okinawa Trough. Bull. Earthquake Res. Inst. Univ. Tokyo, 66, 37-70.

Hsin, Y. C., C. R. Wu, and P. T. Shaw, 2008: Spatial and temporal variations of the Kuroshio east of Taiwan, 1982-2005: A numerical study. J. Geophys. Res., 113, doi: 10.1029/2007jc004485. [Link]
Hsu, S.-K., 2017: Geological Investigation of Mineral Resource Potential in the Offshore Northeastern Taiwan: High Resolution Sonar and Magneic Surveys (2/4). Report of Central Geological Survey, 106-13. (in Chinese with English abstract)

Inagaki, F., M. M. M. Kuypers, U. Tsunogai, J. Ishibashi, K. Nakamura, T. Treude, S. Ohkubo, M. Nakaseama, K. Gena, H. Chiba, H. Hirayama, T. Nunoura, K. Takai, B. B. Jorgensen, K. Horikoshi, and A. Boetius, 2006: Microbial community in a sediment-hosted $\mathrm{CO}_{2}$ lake of the southern Okinawa Trough hydrothermal system. Proc. Natl. Acad. Sci., 103, 14164-14169, doi: 10.1073/pnas.0606083103. [Link]

Ishibashi, J., T. Noguchi, T. Toki, S. Miyabe, S. Yamagami, Y. Onishi, T. Yamanaka, Y. Yokoyama, E. Omori, Y. Takahashi, K. Hatada, Y. Nakaguchi, M. Yoshizaki, U. Konno, T. Shibuya, K. Takai, F. Inagaki, and S. Kawagucci, 2014: Diversity of fluid geochemistry affected by processes during fluid upwelling in active hydrothermal fields in the Izena Hole, the middle Okinawa Trough back-arc basin. Geochem. J., 48, 357-369, doi: 10.2343/geochemj.2.0311. [Link]

Ishibashi, J., F. Ikegami, T. Tsuji, and T. Urabe, 2015: Hydrothermal activity in the Okinawa Trough backarc basin: Geological background and hydrothermal mineralization. In: Ishibashi, J., K. Okino, and M. Sunamura (Eds.), Subseafloor Biosphere Linked to Hydrothermal Systems, Springer, Tokyo, 337-359, doi: 10.1007/978-4-431-54865-2_27. [Link]

Jian, Z., P. Wang, Y. Saito, J. Wang, U. Pflaumann, T. Oba, and X. Cheng, 2000: Holocene variability of the Kuroshio current in the Okinawa Trough, northwestern Pacific Ocean. Earth Planet. Sci. Lett., 184, 305-319, doi: 10.1016/S0012-821X(00)00321-6. [Link]

Kelley, D. S., S. M. Carbotte, D. W. Caress, D. A. Clague, J. R. Delaney, J. B. Gill, H. Hadaway, J. F. Holden, E. E. E. Hooft, J. P. Kellogg, M. D. Lilley, M. Stoermer, D. Toomey, R. Weekly, and W. S. D. Wilcock, 2012: Endeavour Segment of the Juan de Fuca Ridge: One of the most remarkable places on Earth. Oceanography, 25, 44-61, doi: 10.5670/oceanog.2012.03. [Link]

Kimura, M., S. Uyeda, Y. Kato, T. Tanaka, M. Yamano, T. Gamo, H. Sakai, S. Kato, E. Izawa, and T. Oomori, 1988: Active hydrothermal mounds in the Okinawa Trough backarc basin, Japan. Tectonophysics, 145, 319-324, doi: 10.1016/0040-1951(88)90203-x. [Link]

Kinoshita, M. and M. Yamano, 1997: Hydrothermal regime and constraints on reservoir depth of the Jade site in the Mid-Okinawa Trough inferred from heat flow measurements. J. Geophys. Res., 102, 3183-3194, doi: 10.1029/96jb03556. [Link]

Lee, C.-S., G. G. Shor, L. D. Bibee, R. S. Lu, and T. W. C. Hilde, 1980: Okinawa Trough: Origin of a backarc basin. Mar. Geol., 35, 219-241, doi: 10.1016/ 
0025-3227(80)90032-8. [Link]

Letouzey, J. and M. Kimura, 1986: The Okinawa Trough: Genesis of a back-arc basin developing along a continental margin. Tectonophysics, 125, 209-230, doi: 10.1016/0040-1951(86)90015-6. [Link]

Liang, W.-D., T. Tang, Y. Yang, M. Ko, and W.-S. Chuang, 2003: Upper-ocean currents around Taiwan. Deep-Sea Res. Part II-Top. Stud. Oceanogr., 50, 1085-1105, doi: 10.1016/s0967-0645(03)00011-0. [Link]

Liu, C. S., 2017: Geological Investigation of Mineral Resource Potential in the Offshore Northeastern Taiwan: Seismic Reflection and Chirp Sonar Investigation (2/4). Report of Central Geological Survey, 106-12-A. (in Chinese with English abstract)

Luders, V. and S. Niedermann, 2010: Helium isotope composition of fluid inclusions hosted in massive sulfides from modern submarine hydrothermal systems. Econ. Geol., 105, 443-449, doi: 10.2113/gsecongeo.105.2.443. [Link]

Miki, M., 1995: Two-phase opening model for the Okinawa Trough inferred from paleomagnetic study of the Ryukyu arc. J. Geophys. Res., 100, 8169-8184, doi: 10.1029/95jb00034. [Link]

Minami, H. and Y. Ohara, 2017: The Gondou hydrothermal field in the Ryukyu Arc: A huge hydrothermal system on the flank of a caldera volcano. Geochem. Geophys. Geosyst., 18,3489-3516, doi: 10.1002/2017GC006868. [Link]

Nedimović, M. R., S. Mazzotti, and R. D. Hyndman, 2003: Three-dimensional structure from feathered two-dimensional marine seismic reflection data: The eastern Nankai Trough. J. Geophys. Res., 108, doi: 10.1029/2002jb001959. [Link]

Nozaki, T., J.-I. Ishibashi, K. Shimada, T. Nagase, Y. Takaya, Y. Kato, S. Kawagucci, T. Watsuji, T. Shibuya, R. Yamada, T. Saruhashi, M. Kyo, and K. Takai, 2016: Rapid growth of mineral deposits at artificial seafloor hydrothermal vents. Sci. Rep., 6, doi: 10.1038/ srep22163. [Link]

Nunoura, T., H. Oida, M. Nakaseama, A. Kosaka, S. B. Ohkubo, T. Kikuchi, H. Kazama, S. Hosoi-Tanabe, K. Nakamura, M. Kinoshita, H. Hirayama, F. Inagaki, U. Tsunogai, J. Ishibashi, and K. Takai, 2010: Archaeal diversity and distribution along thermal and geochemical gradients in hydrothermal sediments at the Yonaguni Knoll IV hydrothermal field in the Southern Okinawa Trough. Appl.Environ. Microbiol., 76, 11981211, doi: 10.1128/AEM.00924-09. [Link]

Park, J. O., H. Tokuyama, M. Shinohara, K. Suyehiro, and A. Taira, 1998: Seismic record of tectonic evolution and backarc rifting in the southern Ryukyu island arc system. Tectonophysics, 294, 21-42, doi: 10.1016/ s0040-1951(98)00150-4. [Link]

Planke, S., T. Rasmussen, S. S. Rey, and R. Myklebust,
2005: Seismic characteristics and distribution of volcanic intrusions and hydrothermal vent complexes in the Vøring and Møre basins. In: Doré, A. G. and B. A. Vining (Eds.), Petroleum Geology: North-West Europe and Global Perspectives - Proceedings of the 6th Petroleum Geology Conference, Geological Society, London, Petroleum Geology Conference series, Volume 6, Geological Society of London, 833-844, doi: 10.1144/0060833. [Link]

Randen, T., S. I. Pedersen, and L. Sønneland, 2001: Automatic extraction of fault surfaces from three-dimensional seismic data. SEG Technical Program Expanded Abstracts 2001, Society of Exploration Geophysicists, 551-554, doi: 10.1190/1.1816675. [Link]

Sakai, H., T. Gamo, E.-S. Kim, M. Tsutsumi, T. Tanaka, J. Ishibashi, H. Wakita, M. Yamano, and T. Oomori, 1990: Venting of carbon dioxide-rich fluid and hydrate formation in mid-Okinawa trough backarc basin. Science, 248, 1093-1096, doi: 10.1126/science. 248.4959.1093. [Link]

Shinjo, R. and Y. Kato, 2000: Geochemical constraints on the origin of bimodal magmatism at the Okinawa Trough, an incipient back-arc basin. Lithos, 54, 117137, doi: 10.1016/s0024-4937(00)00034-7. [Link]

Shinjo, R., S. L. Chung, Y. Kato, and M. Kimura, 1999: Geochemical and $\mathrm{Sr}-\mathrm{Nd}$ isotopic characteristics of volcanic rocks from the Okinawa Trough and Ryukyu Arc: Implications for the evolution of a young, intracontinental back arc basin. J. Geophys. Res., 104, 10591-10608, doi: 10.1029/1999jb900040. [Link]

Shyu, C.-T. and C.-S. Liu, 2001: Heat flow of the southwestern end of the Okinawa Trough. Terr. Atmos. Ocean. Sci., 12, 305-317, doi: 10.3319/ TAO.2001.12.S.305(ODP). [Link]

Sibuet, J.-C., J. Letouzey, F. Barbier, J. Charvet, J.-P. Foucher, T. W. C. Hilde, M. Kimura, L.-Y. Chiao, B. Marsset, C. Muller, and J.-F. Stéphan, 1987: Back arc extension in the Okinawa Trough.J. Geophys.Res., 92, 14041-14063, doi: 10.1029/JB092iB13p14041. [Link]

Sibuet, J.-C., B. Deffontaines, S.-K. Hsu, N. Thareau, J.-P. Le Formal, C.-S. Liu, and ACT party, 1998: Okinawa Trough backarc basin: Early tectonic and magmatic evolution. J. Geophys. Res., 103, 30245-30267, doi: 10.1029/98jb01823. [Link]

Sun, Q., S. Wu, J. Cartwright, S. Wang, Y. Lu, D. Chen, and D. Dong, 2014: Neogene igneous intrusions in the northern South China Sea: Evidence from high-resolution three dimensional seismic data. Mar. Petrol. Geol., 54, 83-95, doi: 10.1016/j.marpetgeo.2014.02.014. [Link]

Tang, T. Y., J. H. Tai, and Y. J. Yang, 2000: The flow pattern north of Taiwan and the migration of the Kuroshio. Cont. Shelf Res., 20, 349-371, doi: 10.1016/ s0278-4343(99)00076-x. [Link] 
Tivey, M. K., 2007: Generation of seafloor hydrothermal vent fluids and associated mineral deposits. Oceanography, 20, 50-65, doi: 10.5670/oceanog.2007.80. [Link]

Toki, T., M. Itoh, D. Iwata, S. Ohshima, R. Shinjo, J. Ishibashi, U. Tsunogai, N. Takahata, Y. Sano, T. Yamanaka, A. Ijiri, N. Okabe, T. Gamo, Y. Muramatsu, Y. Ueno, S. Kawagucci, and K. Takai, 2016: Geochemical characteristics of hydrothermal fluids at Hatoma Knoll in the southern Okinawa Trough. Geochem. J., 50, 493-525, doi: 10.2343/geochemj.2.0449. [Link]

Tsai, C.-H., S.-K. Hsu, Y.-F. Chen, H.-S. Lin, S.-Y. Wang, S.-C. Chen, C.-W. Liang, and Y.-Y. Cho, 2019: Gas plumes and near-seafloor bottom current speeds of the southernmost Okinawa Trough determined from echo sounders. Terr. Atmos. Ocean. Sci., 30, 649-674, doi: 10.3319/TAO .2019.07.07.01. [Link]

Uyeda, S., 1987: Active hydrothermal mounds in the Okinawa back-arc trough. Eos, Trans., $A G U, 68,737$, doi: 10.1029/eo068i036p00737-01. [Link]
Von Damm, K., 1990: Seafloor hydrothermal activity: Black smoker chemistry and chimneys. Annu. Rev. Earth Planet. Sci., 18, 173-204, doi: 10.1146/annurev. earth.18.1.173. [Link]

Wang, C. C., 2016: Investigation of Mineral Resource Potential in the Offshore Northeastern Taiwan: Video Surveys and Sampling of Seafloor Mineral Deposits (1/4). Report of Central Geological Survey, 105-14-B. (in Chinese with English abstract)

Yamano, M., S. Uyeda, J.-P.Foucher, and J.-C. Sibuet, 1989: Heat flow anomaly in the middle Okinawa Trough. Tectonophysics, 159, 307-318, doi: 10.1016/00401951(89)90136-4. [Link]

Yang, Y., C.-T. Liu, J.-H. Hu, and M. Koga, 1999: Taiwan Current (Kuroshio) and impinging eddies. J. Oceanogr., 55, 609-617, doi: 10.1023/A:1007892819134. [Link]

Yilmaz, Ö., 2001: Seismic Data Analysis: Processing, Inversion, and Interpretation of Seismic Data, Society of Exploration Geophysicists, 2065 pp, doi: 10.1190/1.9781560801580. [Link] 